\title{
HUBUNGAN DERAJAT KEPARAHAN SIROSIS HATI DAN NILAI LAJU GLOMERULUS PADA SIROSIS HATI
}

\author{
${ }^{1}$ Pamela M. Poluan \\ ${ }^{2}$ Ventje Kawengian \\ ${ }^{2}$ Cerelia Sugeng
}

\author{
${ }^{1}$ Kandidat Skripsi Fakultas Kedokteran Universitas Sam Ratulangi Manado \\ ${ }^{2}$ Bagian Ilmu Penyakit Dalam Fakultas Kedokteran Universitas Sam Ratulangi Manado \\ Email: ppoluan11_237@yahoo.com
}

\begin{abstract}
Liver cirrhosis is often associated with impaired renal function. This can be due to disturbances of hemodynamic and neurohormonal systems and increased activity of the sympathetic nervous system. This will lead to a decrease in glomerular filtration rate (GFR). This study aimed to find out the connection of the liver cirrhosis degree and GFR values in liver cirrhosis subjects. This study was a cross-sectional design. Samples were 30 liver cirrhosis cases' medical records at BLU Prof. Dr R.D Kandou Hospital Manado in the period of October 2013 to October 2014.The medical record data included age, gender, values of albumin, bilirubin, and creatinine, Child's score, and the GFR values by using CKD-EPI formula. The corrrelation of the liver cirrhosis degrees and GFR values was tested by using the Spearman correlation test. The results showed that there was a negative, not significant correlation between class B Child's score and GFR ( $r=-0.231, p=0.618)$; a positive, not significant correlation between class C Child's score and GFR $(r=0.188, p=0.428)$, and btween Child's score and GFR $(r=0.118, p=0.533)$
\end{abstract}

Conclusion: There was no significant correlation between the liver cirrhosis degree (Child's score) and GFR values.

Keywords: liver cirhhosis, Child's score, GFR

\begin{abstract}
Abstrak: Sirosis hati sering disertai gangguan fungsi ginjal. Hal tersebut dapat disebabkan adanya gangguan sistem hemodinamik dan neurohormonal, serta peningkatan aktivitas sistem saraf simpatis. Gangguan ini akan memicu penurunan laju filtrasi glomerulus (LFG). Penelitian ini bertujuan untuk melihat hubungan derajat keparahan sirosis hati dengan nilai laju filtrasi glomerulus pada subyek sirosis hati. Penelitian ini menggunakan desain potong lintang. Sampel peneltian ini berjumlah 30 rekam medik subyek sirosis hati yang tercatat di BLU RSUP Prof. Dr. R.D. Kandou Manado periode Oktober 2013 sampai Oktober 2014. Data rekam medik tersebut mencakup umur, jenis kelamin, nilai albumin, bilirubin, kreatinin, skor Child, dan nilai LFG menggunakan formula CKD-EPI. Hubungan derajat keparahan Child dengan LFG diuji dengan uji korelasi Spearman. Hasil uji korelasi Spearman menunjukkan bahwa terdapat hubungan negatif dan tidak signifikan antara skor Child kelas B dengan LFG $(\mathrm{r}=-0,231, \mathrm{p}=0,618)$, hubungan positif dan tidak signifikan antara skor Child kelas Cdengan LFG $(r=0,188, p=0,428)$, serta skor Child dengan LFG $(r=0,118, p=0,533)$. Simpulan: Tidak terdapat hubungan signifikan antara derajat keparahan sirosis hati (Skor Child) dengan nilai LFG.
\end{abstract}

Kata kunci: sirosis hati, skor Child, LFG

Sirosis hati (SH) adalah sekelompok penyakit hati kronik yang mengakibatkan kerusakan sel hati dan sel tersebut digantikan oleh jaringan parut sehingga 
terjadi penurunan jumlah jaringan hati normal. Peningkatan jaringan parut tersebut menimbulkan distorsi struktur hati yang normal, sehingga terjadi gangguan aliran darah melalui hati dan terjadi gangguan fungsi hati. ${ }^{1-3}$ SH secara klinis dibagi menjadi sirosis hati kompensata yang berarti belum adanya gejala klinis yang nyata dan sirosis hati dekompensata yang ditandai gejala-gejala tanda klinis yang jelas. $^{2,3}$

World Health Organization (WHO) pada tahun 2004 melaporkan bahwa sirosis hati merupakan penyebab kematian ke-18 di dunia dengan prevalensi $1,3 \% .^{3}$ Insidens di Amerika diperkirakan terdapat 360 per 100.000 penduduk, dengan penyebab sebagian besar akibat penyakit hati alkoholik dan infeksi virus kronik. Di Indonesia data prevalensi sirosis hati belum ada. Rumah sakit Dr. Sardjito Yogyakarta melaporkan bahwa pada tahun 2004, jumlah pasien sirosis hati berkisar 4,1\% dari total pasien yang dirawat di bagian Penyakit Dalam. ${ }^{3}$

Prognosis $\mathrm{SH}$ dipengaruhi berbagai faktor, seperti etiologi, beratnya kerusakan hati, komplikasi dan penyakit lain yang menyertai. ${ }^{4}$ Klasifikasi Child merupakan salah satu parameter untuk menilai derajat keparahan pasien sirosis hepatis, dimana variabelnya meliputi konsentrasi bilirubin, albumin, ada tidaknya ascites dan ensefalopati, serta status nutrisi. Klasifikasi ini terdiri dari Child kelas A,B dan C.,

Pasien dengan sirosis hati dalam perjalanan penyakitnya, sering mengalami gangguan ginjal, dimana pada stadium awal gangguan fungsi ginjal ini bersifat reversibel, yaitu dapat membaik dengan intervensi medis.Stadium ekstrim dari gangguan fungsi ginjal ini adalah sindrom hepatorenal (SHR) yang umumnya bersifat ireversibel. SHR adalah gangguan fungsi ginjal sekunder pada penyakit hati tingkat berat baik akut maupun kronik yang bersifat fungsional dan progresif. Sekitar $20 \%$ pasien sirosis hati dengan asites disertai fungsi ginjal yang normal, akan mengalami SHR setelah 1 tahun, dan 39\% setelah 5 tahun perjalanan penyakit. 2,5,6
Gangguan fungsi ginjal yang terjadi pada pasien sirosis hati dapat disebabkan adanya gangguan hemodinamik, terutama vasodilatasi perifer, yang akan diikuti aktivasi hormon vasokonstriksi, sistem neurohormonal seperti renin-aldosteron, vasopresin, endotelin dan peningkatan aktivitas sistem saraf simpatis. Gangguan ini akan memicu retensi air dan natrium di ginjal, dan penurunan laju filtrasi glomerulus (LFG) ginjal. ${ }^{5-7}$

Penilaian fungsi ginjal dapat dilakukan dengan cara pengukuran LFG dan penghitungan LFG. Pengukuran LFG secara langsung dengan substansi eksogen atau endogen pada pelaksanaannya sulit dan tidak praktis sehingga saat ini di klinik digunakan penghitungan estimasi laju filtrasi glomerulus (eLFG) yang terdiri dari formula Cockcroft-Gault (eLFG ${ }_{\mathrm{CG}}$ ), formula Modification of Diet in Renal Disease (eLFG ${ }_{\text {MDRD }}$ ) dan formula Chronic Kidney Disease-Epidemiology (eLFG EPI). ${ }^{8}$ Menurut Chronic Kidney Disease Epidemiology Collaboration, formula eLFG $_{\text {CKD-EPI memiliki akurasi sedikit lebih }}$ baik dari formula eLFG ${ }_{M D R D}$ dalam penentuan nilai eLFG. ${ }^{9,10}$

Gangguan fungsi ginjal pada pasien dengan sirosis, terutama berkaitan dengan gangguan fungsi peredaran darah, dimana terjadi penurunan tahanan pada pembuluh darah sistemik akibat vasodilatasi arteri primer yang meningkatkan produksi atau aktivitas dari faktor vasodilator, terutama nitrat oksida, karbon monoksida, endogenous-cannabinoids yang terutama terdapat pada sirkulasi splanknikus. ${ }^{11}$ Pada tahap awal sirosis, dengan tingkat hipertensi portal moderat, terjadi peningkatan curah jantung yang mengkompensasi untuk penurunan resistensi pembuluh darah sistemik, yang memungkinkan tekanan arteri dan volume darah arteri efektif untuk tetap dalam batas normal. Pada sirosis stadium lanjut terjadi penurunan resistensi pembuluh darah yang nyata, dan tambahan peningkatan curah jantung tidak bisa mengkompensasi, yang mengarah pada arteri underfilling. Gangguan ginjal sering terjadi pada sirosis 
yang telah lanjut dengan asites dan edema. ${ }^{2,5,11}$ Pada sirosis tingkat lanjut, tekanan arteri harus dijaga melalui sistem vasokonstriktor termasuk reninangiotensin, sistem saraf simpatik, dan hipersekresi hormon antidiuretik non osmotik. $^{2,5}$ Mekanisme kompensasi ini membantu ginjal mempertahankan volume darah arteri efektif dan tekanan arterial relatif normal tetapi memiliki efek penting pada fungsi ginjal, terutama natrium dan retensi air zat terlarut bebas, yang mungkin akhirnya menyebabkan asites dan edema pada gangguan ginjal dengan menyebabkan vasokonstriksi intrarenal dan hipoperfusi. Gangguan ini akan menyebabkan penurunan laju filtrasi glomerulus. ${ }^{2,5-7,11}$

\section{METODE PENELITIAN}

Penelitian ini menggunakan jenis penelitian analitik retrospektif dengan pendekatan potong lintang, teknik pengambilan sampel yang digunakan yaitu secara consecutive sampling. Penelitian ini dilaksanakan di RSUP Prof. Dr. R. D. Kandou Manado selama 2 (dua) bulan, mulai November 2014 - Desember 2014.

Populasi penelitian ialah rekam medik subyek sirosis hati yang dirawat di RSUP Prof. Dr. R.D. Kandou Manado periode Oktober 2013 - Oktober 2014. Sampel berjumlah 30 rekam medik subyek sirosis hati. Teknik analisis data dengan menggunakan analisis univariat dalam menilai karakteristik sampel penelitian serta analisis bivariat menggunakan uji korelasi spearman dengan tingkat kemaknaan $\mathrm{p}=<0,05$. Penelitian ini menggunakan data rekam medik yang mencakupumur, jenis kelamin, nilai albumin, bilirubin, kreatinin, skor child, dan nilai LFG menggunakan formula CKDEPI. Pengolahan data dan analisis data menggunakan software program komputer untuk uji korelasi Spearman.

\section{HASIL PENELITIAN}

Tabel 1 memperlihatkan karakteristik sampel penelitian berdasarkan umur, nilai albumin, bilirubin, kreatinin, dan eLFG CKD-EPI.
Tabel 1. Karakteristik Sampel Penelitian

\begin{tabular}{cccccc}
\hline Variabel & $\mathrm{N}$ & Min & Maks & Rerata & SD \\
\hline $\begin{array}{c}\text { Umur } \\
\text { Albumin }\end{array}$ & 30 & 27 & 77 & 54,13 & 12,182 \\
$\begin{array}{c}\text { (gr/dL }) \\
\text { Bilirubin } \\
\text { (mg/dL) }\end{array}$ & 30 & 0,2 & 33,9 & 5,01 & 7,0642 \\
$\begin{array}{c}\text { Kreatinin } \\
\text { (mg/dL) } \\
\text { eLFG CKD- }\end{array}$ & 30 & 0,4 & 3,2 & 1,237 & 0,7025 \\
$\quad$ EPI & & 15 & 119 & 71,73 & 33,001 \\
\hline
\end{tabular}

$\mathrm{N}=$ jumlah sampel, $\min =$ nilai terendah, maks = nilai tertinggi, $\mathrm{SD}=$ standar deviasi

Berdasarkan umur, terlihat bahwa umur rata-rata subyek sirosis hati yaitu 54,13 tahun, standar deviasi 12,182 dengan umur subyek termuda yaitu 27 tahun dan tertua 77 tahun.

Berdasarkan nilai albumin, terlihat bahwa rata-rata nilai albumin subyek sirosis hati yaitu 2,741 gr/dL, standar deviasi 0,6616 dengan nilai albumin terendah yaitu $1,7 \mathrm{gr} / \mathrm{dL}$, dan nilai albumin tertinggi yaitu 4,4 gr/dL.

Berdasarkan nilai bilirubin, terlihat bahwa rata-rata nilai bilirubin subyek sirosis hati yaitu 5,01, standar deviasi 7,0642 dengan nilai bilirubin terendah yaitu $0,2 \mathrm{mg} / \mathrm{dL}$, dan nilai bilirubin tertinggi yaitu 33,9 mg/dL.

Berdasarkan nilai kreatinin, terlihat bahwa rata-rata nilai kreatinin subyek sirosis hati yaitu 1,237, standar deviasi 0,7025 dengan nilai kreatinin terendah yaitu 0,4 mg/dL, dan nilai kreatinin tertinggi yaitu $3,2 \mathrm{mg} / \mathrm{dL}$.

Berdasarkan nilai eLFG CKD-EPI, terlihat bahwa rata-rata eLFG subyek sirosis hati yaitu 71,73 , standar deviasi 33,001 dengan eLFG terendah yaitu 15 dan eLFG tertinggi yaitu 119.

Tabel 2. Distribusi frekuensi subyek sirosis hati menurut jenis kelamin

\begin{tabular}{ccc}
\hline Jenis Kelamin & $\mathrm{n}$ & $\%$ \\
\hline Laki-laki & 16 & 53,3 \\
Perempuan & 15 & 46,7 \\
\hline Total & 30 & 100 \\
\hline
\end{tabular}

$\mathrm{n}=$ jumlah sampel, $\%=$ persentase 
Berdasarkan jenis kelamin, terlihat bahwa subyek sirosis hati dengan jenis kelamin laki-laki berjumlah 16 orang (53,3\%) yaitu lebih banyak dari pada jumlah subyek sirosis hati dengan jenis kelamin wanita berjumlah 15 orang (46,7\%).

Tabel 3. Distribusi frekuensi subyek sirosis hati menurut Klasifikasi Child

\begin{tabular}{ccc}
\hline Klasifikasi Child & $\mathrm{n}$ & $\%$ \\
\hline Kelas A & 3 & 9,7 \\
Kelas B & 7 & 22,6 \\
Kelas C & 20 & 64,5 \\
\hline Total & 30 & 100 \\
\hline
\end{tabular}

Berdasarkan Klasifikasi Child terlihat bahwa subyek sirosis hati dengan derajat keparahan Child kelas A berjumlah 3 orang $(9,7 \%)$, Kelas $\mathrm{B}$ berjumlah 7 orang (22,6\%), dan Kelas C (64,5\%)

Tabel 4. Analisis Hubungan Derajat Keparahan Child kelas B dengan Nilai LFG pada Subyek Sirosis Hati

\begin{tabular}{ccc}
\hline Hubungan Variabel & $\begin{array}{c}\text { Koefisien } \\
\text { korelasi }\end{array}$ & $\begin{array}{c}\text { Kemaknaa } \\
\mathrm{n}\end{array}$ \\
\hline Klasifikasi Child B- & $\mathrm{r}=-$ & $\mathrm{p}=0,618$ \\
LFG & 0,231 & \\
\hline
\end{tabular}

Keterangan: uji korelasi Spearman

Hasil analisis statistik dengan uji korelasi Spearman antara derajat keparahan Child kelas B dengan nilai laju filtrasi glomerulus diperoleh hubungan tidak bermakna $(p=0,618 . r=-0,231)$. Hasil ini menunjukkan tidak adanya hubungan ( $\mathrm{p}$ $>0,05$ ) antara derajat keparahan sirosis hati dengan nilai laju filtrasi glomerulus pada subyek sirosis hati.

Tabel 5. Analisis Hubungan Derajat Keparahan Child kelas C dengan Nilai LFG pada Subyek Sirosis Hati (uji korelasi Spearman)

\begin{tabular}{ccc}
\hline Hubungan Variabel & $\begin{array}{c}\text { Koefisien } \\
\text { korelasi }\end{array}$ & $\begin{array}{c}\text { Kemaknaa } \\
\mathrm{n}\end{array}$ \\
\hline $\begin{array}{c}\text { Klasifikasi Child C- } \\
\text { LFG }\end{array}$ & $\mathrm{r}=0,188$ & $\mathrm{p}=0,428$ \\
\hline
\end{tabular}

Hasil analisis statistik dengan uji korelasi Spearman antara derajat keparahan Child kelas C dengan nilai laju filtrasi glomerulus diperoleh hubungan tidak bermakna $(p=0,428 . r=0,188)$. Hasil ini menunjukkan tidak adanya hubungan ( $\mathrm{p}>$ $0,05)$ antara derajat keparahan sirosis hati dengan nilai laju filtrasi glomerulus pada subyek sirosis hati.

Tabel 6. Analisis Hubungan Derajat Keparahan Child dengan Nilai LFG pada Subyek Sirosis Hati

\begin{tabular}{ccc}
\hline Hubungan Variabel & $\begin{array}{c}\text { Koefisien } \\
\text { korelasi }\end{array}$ & $\begin{array}{c}\text { Kemaknaa } \\
\mathrm{n}\end{array}$ \\
\hline $\begin{array}{c}\text { Klasifikasi Child - } \\
\text { LFG }\end{array}$ & $\mathrm{r}=0,118$ & $\mathrm{p}=0,533$ \\
\hline
\end{tabular}

Hasil analisis statistik dengan uji korelasi Spearman antara derajat keparahan sirosis hati dengan nilai laju filtrasi glomerulus diperoleh hubungan tidak bermakna ( $p=0,533, r=0,118)$. Hasil ini menunjukkan tidak adanya hubungan ( $\mathrm{p}>$ 0,05 ) antara derajat keparahan sirosis hati dengan nilai laju filtrasi glomerulus pada subyek sirosis hati

\section{BAHASAN}

Gangguan fungsi ginjal pada pasien dengan sirosis, terutama berkaitan dengan gangguan fungsi peredaran darah, dimana terjadi penurunan tahanan pada pembuluh darah sistemik akibat vasodilatasi arteri primer yang meningkatkan produksi atau aktivitas dari faktor vasodilator, terutama nitrat oksida, karbon monoksida, endogenous-cannabinoids yang terutama terdapat pada sirkulasi splanknikus. ${ }^{11}$

Gangguan ginjal sering terjadi pada sirosis yang telah lanjut dengan asites dan edema. $^{2,5,11}$ Pada sirosis tingkat lanjut, tekanan arteri harus dijaga melalui sistem vasokonstriktor, termasuk reninangiotensin, sistem saraf simpatik, dan hipersekresi hormon antidiuretik non osmotik. $^{2,5}$ Mekanisme kompensasi ini membantu mempertahankan volume darah arteri efektif dan tekanan arterial relatif normal tetapi memiliki efek penting pada 
fungsi ginjal, terutama natrium dan retensi air zat terlarut bebas, yang mungkin akhirnya menyebabkan asites dan edema pada gangguan ginjal dengan menyebabkan vasokonstriksi intrarenal dan hipoperfusi. Gangguan ini akan menyebabkan

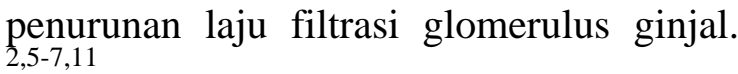

Skor Child, digunakan untuk menilai kondisi umum pasien sirosis hati dan menilai perubahan multiorgan yang disebabkan oleh sirosis hati. Klasifikasi Child berkaitan dengan angka kelangsungan hidup yaitu menilai derajat keparahan berdasarkan skor minimal (6-7), sedang (8-9), dan berat (10-15). Pada Skor Child, kadar serum bilirubin, serum albumin, asites, gangguan neurologis, dan status nutrisi. Kriteria asites dan ensefalopati menggambarkan tingkat beratnya hipertensi portal, sedangkan kriteria lainya yaitu ikterus, albumin, dan status nutrisi menggambarkan fungsi metabolisme hepar. Sintesis dan katabolisme albumin terjadi di hati. Pada sirosis hati akan dijumpai rendahnya produksi albumin. Perubahan serum albumin dapat menunjukkan peningkatan permeabilitas vaskuler karena sepsis dan asites. Pada sirosis hati juga akan dijumpai peningkatan produksi bilirubin. Peningkatan bilirubin juga dapat disebabkan oleh kegagalan fungsi ginjal, proses hemolisis, atau sepsis.

Berdasarkan jenis kelamin, terlihat bahwa proporsi sirosis hati lebih banyak terjadi pada laki-laki yaitu dengan persentase 53,3:46,7. Hal ini tidak jauh berbeda dengan penelitian yang dilakukan oleh Tambunan et al. ${ }^{12}$ tentang karakteristik pasien sirosis di RSU Dr. Soedarso Pontianak bahwa sebanyak 128 pasien (69,6\%) laki-laki dan 56 pasien (30,4\%) perempuan. Kecenderungan ini belum diketahui secara pasti penyebabnya. Lakilaki lebih banyak menderita sirosis hati kemungkinan karena mereka lebih sering terpapar dengan sejumlah agen penyebab sirosis hati, seperti virus hepatitis dan alkohol.

Berdasarkan klasifikasi Child, terlihat bahwa subyek sirosis hati dengan derajat keparahan Child kelas A berjumlah 3 orang (9,7\%), kelas B berjumlah 7 orang (22,6\%), dan kelas C (64,5\%). Penelitian oleh Tambunan et al. ${ }^{19}$ di Pontianak juga menunjukkan hal yang sama dimana sebagian besar pasien sirosis hati sudah masuk dalam golongan kriteria Child B dan C, dimana 6 pasien (3.3\%) tergolong kriteria Child A, 69 pasien (37.5\%) tergolong kriteria Child B dan 98 pasien (53,3\%) tergolong kriteria Child C.

Penelitian yang dilakukan oleh Gunadi $^{13}$ tentang korelasi cystatin C dengan derajat keparahan sirosis hati menurut skor Model of End Stage Liver Disease (MELD) didapatkan korelasi yang bermakna antara kadar cystatin $\mathrm{C}$ dengan derajat keparahan sirosis hati, artinya terdapat hubungan derajat keparahan sirosis hati dengan penurunan fungsi ginjal. Pada penelitian ini berdasarkan analisis korelasi mengguanakan uji korelasi Spearman diperoleh hasil yaitu hubungan tidak bermakna ( $p=0,533, r=0,118)$. Hasil ini menunjukkan tidak adanya hubungan ( $\mathrm{p}>$ 0,05 ) antara derajat keparahan sirosis hati dengan nilai laju filtrasi glomerulus pada subyek sirosis hati. Penelitian ini tidak didapatkan hubungan yang bermakna karena adanya faktor-faktor pencetus lain yang dapat menyebabkan penurunan laju filtrasi glomerulus pada subyek sirosis hati selain fungsi keparahan sirosis hati, seperti infeksi bakteri akut, perdarahan gastrointestinal, dan kadar albumin yang tidak adekuat setelah melakukan terapi parasentesis. $^{2,7}$ Penelitian ini juga menggunakan penanda kreatinin untuk menghitung nilai LFG, dimana penanda ini mempunyai beberapa keterbatasan diantaranya rendahnya sensitivitas untuk mengukur kerusakan fungsi ginjal dan tidak mampu mendeteksi perubahan LFG yang cepat. Publikasi penelitian klinis penyakit ginjal menyebutkan bahwa Cystatin C merupakan penanda yang baik karena zat ini diproduksi oleh sel tubuh secara tetap, difiltrasi melalui glomerulus, tidak disekresi oleh tubuli ginjal, dan tidak dipengaruhi oleh makanan, usia, massa otot 
serta luas permukaan badan. Pada penelitian ini juga tidak menggunakan klasifikasi Child-Pugh yang merupakan modifikasi dari skor Child, dimana klasifikasi Child-Pugh terbukti lebih sensitif karena kriteria status nutrisi pada klasifikasi Child diubah menjadi pemanjangan prothrombin time (PPT), sehingga menghilangkan kriteria yang paling subjektif. ${ }^{4}$

\section{SIMPULAN}

Berdasarkan hasil penelitian dapat disimpulkan bahwa terdapat hubungan negatif yang tidak bermakna antara derajat keparahan sirosis hati menurut klasifikasi Child kelas B dengan nilai laju filtrasi glomerulus, terdapat hubungan positif yang tidak bermakna antara derajat keparahan sirosis hati menurut klasifikasi Child kelas C dengan nilai laju filtrasi glomerulus dan terdapat hubungan positif yang tidak bermakna antara derajat keparahan sirosis hati menurut klasifikasi Child dengan nilai laju filtrasi glomerulus.

\section{SARAN}

Penelitian selanjutnya diharapkan menggunakan rancangan penelitian yang berbeda, dengan jumlah sampel yang lebih banyak dan variabel tertentu yang bertujuan untuk mengidentifikasi hubungan antar variabel.

\section{DAFTAR PUSTAKA}

1. Guha IN, Iredale JP. Clinical and diagnostic aspects of cirrhosis. In: Rodes J, Benhamou JP, Blei AT, Reichen J, Rizzetto M, editor. Textbook of Hepatology: From Basic Science to Clinical Practice. $3^{\text {rd }}$ Ed. Massachusetts: Blackwell Publishing, 2007.

2. Sherlock S, Dooley J. Diseases of The Liver and Biliary System. $11^{\text {th }} \mathrm{Ed}$. Oxford: Blackwell Publishing, 2002.

3. Nurdjanah S. Sirosis hati. Dalam: Sudoyo AW, Setyohadi B, Alwi I, Simadibrata MK, Setiati S, editor. Buku Ajar Ilmu Penyakit Dalam Jilid
I. Edisi V. Jakarta: Pusat Penerbitan Ilmu Penyakit Dalam, 2009.

4. Qamar AA. Liver transplantation. In: Greenberger NJ, Blumberg RS, Burakoff R, editor. Current Diagnosis \& Treatment, Gastroenterology, Hepatology \& Endoscopy. New York: McGrawHill, 2009.

5. Setiawan PB, Kusumobroto H. Sindrom hepatorenal. Dalam: Sudoyo A W, Setyohadi B, Alwi I, Simadibrata MK, Setiati S, editor. Buku Ajar Ilmu Penyakit Dalam Jilid I. Edisi V. Jakarta: Pusat Penerbitan Ilmu Penyakit Dalam, 2009.

6. Gines P, Schrier RW. Renal failure in cirrhosis. N Engl J Med 2009;361:1279-90.

7. Lee JW. Renal dysfunction in patients with chronic liver disease. Electrolytes Blood Press. 2009;7:42-50.

8. Stevens LA, Coresh J, Greene T, Levey AS. Assessing kidney functionmeasured and estimated glomerular filteration rate. $\mathrm{N}$ Engl $\mathrm{J}$ Med 2006;354:2473-83.

9. Bermudez RM, Sanjuan JB, Samper AO, Castan JAB, Garcia G. Assessment of the new CKD-EPI equation for estimating glomerular filtration rate. Nefro J 2010;30(2):185-94.

10.Matsushita K, Mahmoodi BK, Woodward M, Emberson JR, Jafar TH, Jee SH, et al. Comparison of risk prediction using the CKD-EPI equation and the MDRD study equation for estimated glomerular filtration rate. JAMA 2012; 307(18):1941-51.

11. Arroyo V, Fernandez $J$, Gines $P$. Pathogenesis and treatment of hepatorenal syndrome. Seminars in liver disease 2008;28:81-95.

12.Tambunan A, Mulyadi Y, Kahtan MI. Karakteristik Pasien Sirosis Hati di RSUD Dr. Soedarso Pontianak Periode Januari 2008 - Desember 2010.

13.Gunadi H. Korelasi Cystatin C dengan Derajat Keparahan Sirosis Hati Menurut skor Model End Stage Liver Disease. Yogyakarta: Universitas Gadjah Mada, 2010. 